University of Puget Sound

Sound Ideas

All Faculty Scholarship

Faculty Scholarship

11-1-2009

\title{
The Temporal Relationship Between Mass Tourism and Alternative Tourism in Southern Thailand
}

Nick Kontogeorgopoulos

University of Puget Sound, konto@pugetsound.edu

Follow this and additional works at: http://soundideas.pugetsound.edu/faculty_pubs

\section{Citation}

Kontogeorgopoulos, N. (2009). The Temporal Relationship between Mass Tourism and Alternative Tourism in Southern Thailand. Tourism Review International, 13(1), 1-16. doi:doi:10.3727/154427209789130639

This Article is brought to you for free and open access by the Faculty Scholarship at Sound Ideas. It has been accepted for inclusion in All Faculty Scholarship by an authorized administrator of Sound Ideas. For more information, please contact soundideas@pugetsound.edu. 


\title{
THE TEMPORAL RELATIONSHIP BETWEEN MASS TOURISM AND ALTERNATIVE TOURISM IN SOUTHERN THAILAND
}

\author{
NICK KONTOGEORGOPOULOS \\ International Political Economy, University of Puget Sound, Tacoma, Washington, USA
}

\begin{abstract}
The temporal relationship between mass tourism and alternative tourism has received little attention in the tourism literature. This article seeks to address this gap by exploring how the emergence of "soft ecotourism" in Phuket, southern Thailand's preeminent resort destination, challenges the notion that alternative tourism can only precede but never follow the establishment of mass tourism. Based on survey and interview data collected over a 1-year span, this article argues that while Phuket's tourism growth over the past several decades does confirm existing models of the movement from alternative to mass tourism, the activities of sea kayaking operators also illustrate that mass tourism and alternative tourism can coexist at the same time and in the same destination. Further, certain syncretic or hybrid forms of alternative tourism, such as soft ecotourism, may serve as one of the many reasons for the continuing growth of tourism in Phuket, in spite of natural disasters, national political instability, and ample evidence of unsustainable development.
\end{abstract}

Key words: Alternative tourism; Ecotourism; Life cycle; Phuket, Thailand

\section{Introduction}

The temporal relationship between mass tourism and alternative forms of tourism is a topic that is both understudied and poorly understood empirically. Although the issue of what happens to tourism destinations over time has received extensive coverage in the tourism literature (see Butler, 2006a, 2006b), few have explored how alternative and mass tourism specifically relate to one another temporally. In those rare cases when temporal sequencing between mass and alternative tourism is addressed, it is usually assumed that small-scale forms of alternative tourism lead eventually and inevitably to greater numbers of tourists and more activities and facilities oriented toward conventional mass tourism (Butcher, 2003; Weaver, 2006). For example, Butler (1992) claims that "the process of tourism development would appear to be unidirectional; that is, alternative small scale tourism can change to mass conventional tourism ... but mass conventional tourism is highly unlikely to be able to change to alternative small scale tourism" (p. 46). Similarly, Cohen (1989) argues that travelers are "often the spearhead of mass tourist penetration of an area" (p. 134).

There are indeed no examples in the world of a mass tourism destination that has turned (back) 
into an alternative tourism destination. However, what previous analyses of mass and alternative tourism fail to address is whether a tourism area is able to accommodate both mass and alternative tourism simultaneously. Existing models of mass and alternative tourism assume that destinations feature either form of tourism but not both. There also exists an assumption that once mass tourism has developed, alternative tourism will never appear again. To assess whether this is true, this article examines the case study of Phuket, a destination in southern Thailand that includes the island of Phuket and adjoining Ao Phang Nga (Phang Nga Bay). Using models developed by Butler (1980) and Weaver (2000) on the temporal evolution of tourism, this article argues that mass tourism and alternative tourism are not necessarily mutually exclusive, and that mass tourism may in fact create the conditions under which operators come to supply and tourists come to demand certain syncretic forms of alternative tourism.

The Phuket vicinity provides a good case study for the examination of the evolution of tourism. As southern Thailand's most renowned tourism destination for several decades, Phuket has largely followed the classic trajectory from alternative to mass tourism. During the late 1960s and 1970s, Phuket served as a backpacker haven, but by the early 1980s, the island had come to assume a prominent role within Thailand's expanding international mass tourism industry. In the late 1980s and continuing in subsequent decades, sea kayaking companies based in Phuket and operating in Ao Phang Nga began to provide experiences best characterized as alternative tourism. Sea kayaking and other forms of "soft ecotourism" have not and will not replace mass tourism as the prevailing paradigm in Phuket, but they do challenge commonly accepted notions of the direction of change from alternative to mass tourism.

\section{Methods}

This article draws on 14 months of original fieldwork data that were collected in southern Thailand. Though the research initially centered specifically on issues related to ecotourism and community development, the data gathered eventually also revealed certain patterns regarding the temporal relationship between alternative tourism and mass, conventional tourism in southern Tha and. Five separate research trips were taken over a span of 11 years between 1996 and 2007. The research took place in the provinces of Phuket Phang Nga, and Krabi on Thailand's southwes coast (Fig. 1), as well as in Ao Phang Nga Marine National Park, located at the confluence of the three provinces.

The data consist of several components. First using convenience sampling, a total of 445 customers of sea kayaking companies in Phuket completed self-administered surveys. Second, recorded face-to-face semistructured interviews lasting between 45 and 90 minutes were conducted with 112 tourists, 15 tour company representatives, 4 Tourism Authority of Thailand officials, and 11 owners or managers from 8 Phuket-based sea kayaking companies. Third, untaped semistructured interviews were conducted with roughly 250 sea kayaking customers, 36 Thai guides working for sea kayaking companies, and 28 local travel agents or employees of roadside travel kiosks. Finally, 14 months of participant observation, recorded in nearly 200 pages of fieldnotes and conducted, among elsewhere, during 54 trips with 8 sea kay aking companies in Phuket produced pertinen data.

The number of sea kayaking companies operating in Ao Phang Nga has fluctuated in the past decade, especially since the Indian Ocean tsunam of December 2004. As of mid-2007, there were approximately 20 companies based in Phuket that offered some variation of a kayaking day trip in Ao Phang Nga. However, only five companies have existed since the early 1990s. Research was conducted-namely, trips, interviews, and selfadministered surveys-with four of the five companies that have existed since the early 1990 s, as well as with an additional four companies that began operations more recently, but the bulk of the research since the first trip in 1996 took place with SeaCanoe Thailand, the oldest sea kayaking company in the Phuket vicinity.

Founded in 1989 by a Californian named John Gray and two local Thai partners, SeaCanoe experienced a meteoric rise until the late 1990s, by which time several competitors, in some cases former partners or managers, began to closely mimic

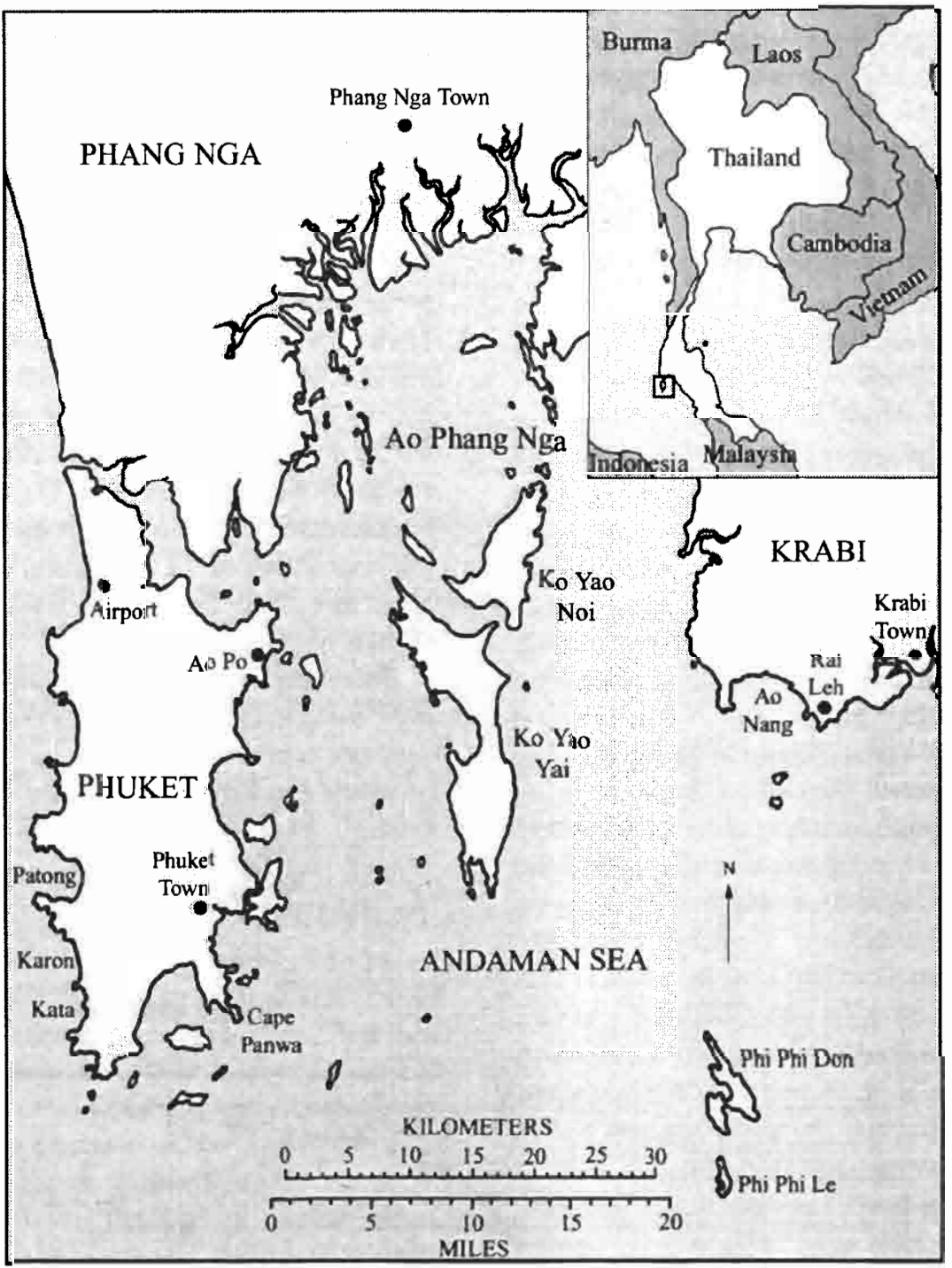

Figure 1. The provinces of Phuket, Phang Nga, and Krabi in southern Thailand.

the itineraries, activities, presentations, and informational materials of SeaCanoe (Motavalli \& Honey, 2002; Shepherd, 2003). During this period of rapid growth, between 1989 and the late 1990s, SeaCanoe received a great deal of national and international recognition, resulting in its eventual inclusion in both green travel guides (Mann, 2002 Neale, 1999) and case studies of successful ecotourism practices (Buckley, 2003; Cater \& Cater, 2007). In 2001, due to internal conflict and his long-standing desire to leave the original company entirely in Thai hands, John Gray left SeaCanoe and began operations under the name John Gray's SeaCanoe (JGSC). As a result of their shared history as part of the first sea kayaking company in southern Thailand and the industry leader fo much of the 1990s, SeaCanoe and JGSC remain the most internationally renowned soft ecotourism companies in the region. Even though JGSC and the original SeaCanoe have lost market share to 
competitors since the late 1990s, they have largely retained their reputations, especially abroad. For this reason, much of the research that provided the dat for this article was conducted with SeaCanoe and JGSC. In particular, customers, staff, and managers from the "two SeaCanoes" served as subjects for $60 \%$ of the self-administered surveys $68 \%$ of taped interviews, and $67 \%$ of untaped interviews.

Temporal Relationship Between Mass Tourism and Alternative Tourism

As noted in the introduction, there exists a general expectation among tourism scholars that mas tourism will inevitably replace alternative tourism. The notion that small-scale forms of alternative tourism are in time supplanted by conventional, tourism are in time supplanted by convers (1980) wellmass tourism directly informs Butler's (1980) wellknown and often cited
(TALC) model (Fig. 2).

According to Butler, tourism areas are dynamic and evolve, hypothetically, through six stages. In the exploration stage, small numbers of "explorer" tourists make individual travel arrangements and follow irregular patterns of visitation. Due to the small number of tourists, the arrival and departure of explorers fail to disrupt the economic and social life of the local residents. The second stage, involvement, is characterized by the involvement of local residents in tourism, whereby incipient advertising, emerge as public and private responses to an increasing demand among tourists for improved facilities. The period of rapid growth in tourism numbers and infrastructure is known as the development stage. Several patterns emerge during this stage: local involvement and control declines rapidly, natural and cultural attractions are developed and marketed, the number of tourists increases rapidly on an annual basis, the physical appearance of the destination is altered noticeably, and local resentment toward tourism and tourists begins to build.

Following development, tourism destination enter the consolidation stage, during which tourist numbers continue to increase but at a slower rate, an area's economy becomes tied more directly to tourism, local opposition and discontent toward tourism build even greater, and well-defined tourism enclaves develop. Stagnation of an area folof locis infastructure, such as accommodations and

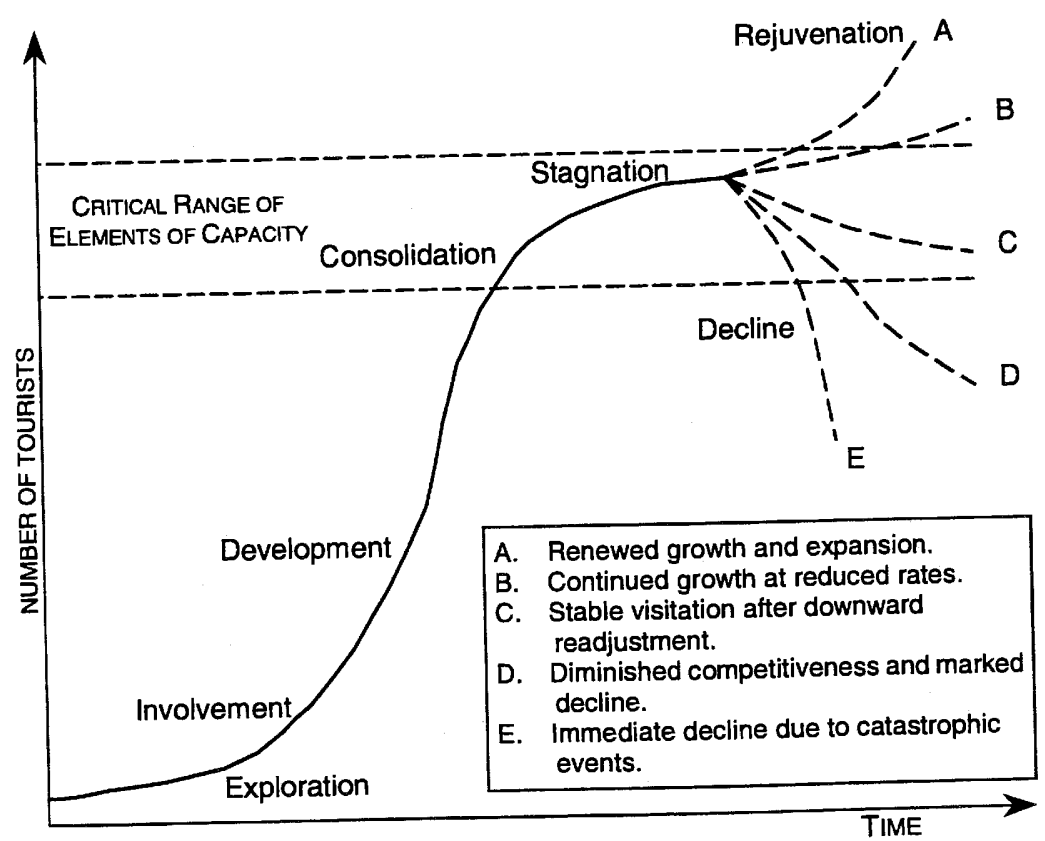

Figure 2. Hypothetical evolution of a tourist area. Source: Butler (1980, p. 7) lows consolidation as tourist numbers peak, environmental and social carrying capacities are met or exceeded, and natural and cultural attractions are superseded by imported artificial facilities. The final stage of Butler's hypothetical evolution is either rejuvenation or decline, with several possible paths in between (curves B to D in Fig. 2).

Since its publication almost 30 years ago, Butler's life-cycle model has been extended, reformulated, and challenged by many authors (Agarwal, 2002; Baum, 1998; Graber, 1997; Johnston, 2001; Moss, Ryan, \& Wagoner, 2003; O'Hare \& Barret, 1997; Priestley \& Mundet, 1998; Russell, 2006). In a sweeping review of TALC-related articles in the English-language tourism literature-a review that according to Butler (2006c) himself "would appear to have more references to the use of the TALC than any other single piece of work" (p. 1) Lagiewski (2006) summarizes the findings of no fewer than 49 major tourism life-cycle studies published between 1980 and 2002.

Clearly, Butler's model continues to serve as a benchmark for assessing the temporal evolution of tourism destinations, and thus, it is useful to compare the example of mass and alternative tourism in Phuket against a theoretical model used so extensively in the field of tourism studies. Moreover, tourism scholars have dissected the TALC mode from almost every conceivable angle, but few have extended the model to the issues of mass and alternative tourism explicitly. A notable exception to this lack of application of the TALC model to mass and alternative tourism is the work of Weaver (2000). Using the level of tourism industry intensity and the amount of tourism sector regulation as his key variables, Weaver (2000) proposes a "broad context model of destination development scenarios" (p. 217) in which fou tourism ideal types are possible (Fig. 3).

Circumstantial alternative tourism (CAT) characterizes destinations that are not only in the explorer or involvement stages of the TALC mode but also feature a loose or laissez-faire regulatory environment. Though also small in scale and intensity, deliberate alternative tourism (DAT) features a conscious attempt by local officials to keep the destination at the involvement stage through a stringent regulatory and policy framework. Although they differ in the control, amount, empha- sis, and time frame of regulation, CAT and DAT feature in common similar markets, attractions, accommodations, and economic impacts that define them as alternative tourism

Acknowledging the difficulty and controversy surrounding efforts to define sustainability in the context of tourism, Weaver states that alternative tourism destinations have the potential to either move in an unregulated manner toward unsustainable mass tourism (UMT) or in a planned and incremental manner toward sustainable mass tourism (SMT). In a later refinement of the original broad-context model, Weaver and Lawton (2002) discuss the possibility of a destination moving from one category to another, and unlike Butler (1980), leave open the possibility of moving from one category to the next in no particular deterministic direction.

Weaver's model of destination development scenarios adds the important variable of regulation to Butler's original life-cycle model. However, the example of soft ecotourism in Phuket illustrates a further complication or possibility that Weaver's model does not accommodate, namely, the coexistence of mass and alternative tourism in the same destination. It should be noted that Weaver (2001, 2002, 2005), among others (Kontogeorgopoulos, 2004a; Lück, 2002) discusses the possibility and even benefits of the intersection between mass tourism and ecotourism, itself an example of alternative tourism. However, there is almost nothing in such discussions on the temporal or evolutionary relationship between mass tourism and ecotourism, or any other form of alternative tourism for that matter. Furthermore, Weaver's model places destinations squarely into mutually exclusive categories, but an important question remains is it possible for a destination to feature elements of both mass tourism and alternative tourism simultaneously? If a destination mostly exhibits characteristics associated with one particular category, such as UMT, does this necessarily mean that the destination lacks segments of the overal industry, or locations within the destination, that in practice exhibit many of the features of another category, such as CAT? To answer these questions, the remaining sections trace the evolution of tourism in Phuket, beginning in the early 1970s. 


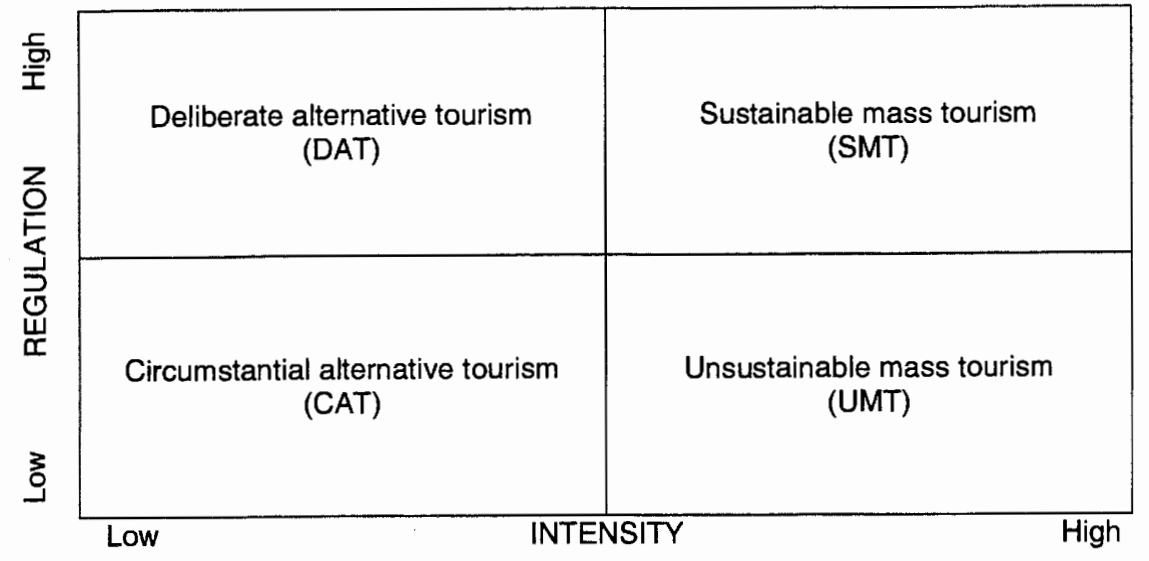

Figure 3. Broad context model of destination development scenarios. Source: Weaver (2000, p. 218).

Phuket: From Backpacker Bungalows to Mass Tourist Resorts

The experience of tourism growth in Phuket confirms the predicted shift from exploration, an circumstantial alternative tourism, to a form of tourism that is so all-encompassing that early form of alternative tourism are completely replaced. The exploration stage in Phuket's touristic evolution occurred during the early 1970s when small groups of youth tourists, or "drifters" in Cohen' (1973) terminology, began to first visit Phuket and other coastal destinations in southern Thailand. In an early study of "bungalow tourism" on the islands of southern Thailand, Cohen (1982) characterizes Phuket as a touristic paradise "marginal to both the life plan of tourists and the ecology and economy of the native society" (p. 3). As more backpackers began to "discover" the marginal paradise of Phuket, the federal government of Thailand commissioned studies on the feasibility of mass tourism development in the area. In 1974 Phuket was identified as a potential mass tourism destination (Huntington Technical Services, 1974). In 1979, the newly revamped Tourism Authority of Thailand (TAT) drafted a comprehensive tourism development plan for Phuket (TAT, 1979). During the same year, the government built an international airport in Phuket, thereby facilitating the rapid subsequent intensification of tourism there.
By the late 1970s, Phuket's tourism industry had entered involvement, the second stage of Butler's hypothetical evolution. In his examination of bungalow tourism on the islands of southern Thailand, Cohen (1982) provides a detailed and prescient snapshot of Phuket's most developed beach during the island's involvement stage. The first set of bungalows on this beach was built in 1976, bu by 1979 , when Cohen conducted his fieldwork the beach was already home to 15 bungalow establishments. In the same year, as mentioned already, the Thai government built an international airport not only in response to rising tourist demand but also, more importantly, as a strategy for tapping into the touristic potential of the island. Cohen's description of Phuket's budding tourism industry fits closely with several other characteristics of the involvement stage, including the high degree of contact between tourists and locals, the spatial definition of an initial market area for tourists, and the rising involvement of locals (in this case urban Sino-Thai elites from Phuket town) in ownership of tourism facilities.

Butler's third stage, development, was also foreseen by Cohen (1982) when he wrote that Phuket's most developed beach "will probably soon move away from small-scale bungalow resorts into larger scale hotel establishments" (p 203). Phuket's transition from involvement to development began in the mid-1980s and is best il- lustrated by the swift increase in the number of tourists visiting Phuket. International tourist arrivals, which stood at approximately 20,000 in 1976 , shot up precipitously during the 1980 s, climbing to just over 530,000 by 1989 (Ludwig, 1976; TAT, 2008). The rapid pace of tourism development continued almost unabated throughout the 1990s and 2000 s, so that by 2004 , there were almost 40 times the number of international tourist arrivals than there were in 1983 (see Fig. 4). After the devastating tsunami in December 2004, international arrivals in Phuket plummeted by 63\%, but have rebounded quickly to levels almost equal to the record high number of arrivals in 2004.

Aside from sizable annual increases in tourists, the patterns exhibited by tourism's growth in Phuket over the past two decades have confirmed many other characteristics of the development stage, including institutionalization, the swelling of tourist numbers beyond the size of the local population (Thaitakoo, 1994), the import of labor and tourist-oriented auxiliary facilities (Kontogeorgopoulos, 1998), the erosion of local ownership and control (Ing, 1988a), changes in the physical appearance of the area (Wong, 1995), and the surfacing of anti-tourist attitudes and actions among some local residents (Pleumarom, 1994 2001).

If one were to look only at the increase in the number of international tourist arrivals to Phuket, it would seem indisputable that Phuket has, since

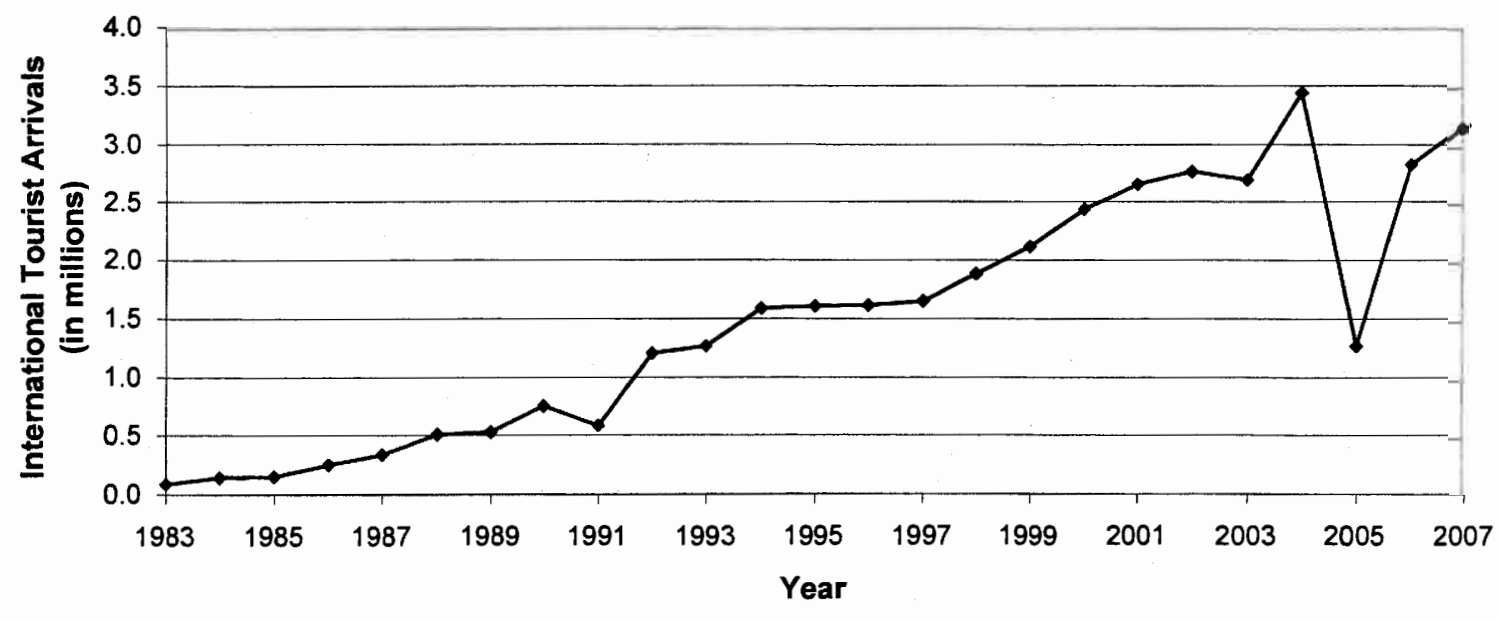

Figure 4. International tourist arrivals in Phuket, 1983-2007. Source: Tourism Authority of Thailand (2008). the mid-1980s, been proceeding through the development stage of its evolution. What is most interesting about Phuket, however, is not the rapi growth of tourism but that this growth has occurred in spite of and contrary to the many predic tions of critics who have continued to sound the death knell for Phuket as a destination. Criticism of the pace and nature of tourism development in Phuket first emerged in the early years of the development stage (Ing, 1988b; Janviroj, 1988) and have continued uninterrupted since then (Lertkittisuk, 1992a; Morison, 2007; Ross, 2002; Viviano 2002). Indeed, as any visitor to Phuket's most developed beaches, such as Patong and Karon, during the past 20 years can attest, and as many crit ics have observed, tourism has seemed to expand in a reckless and unsustainable manner, with no in of restraint or planning.

On a small island with just over 300,000 permanent residents, a 145-fold increase in the number of international tourists in just 18 years (be tween 1986 and 2004) was bound to have social, environmental, and economic repercussions. With perpetually growing tourist numbers has come overcrowding and pressure on local residents to cope with ever-increasing numbers of foreigners There are, at any given time, as many foreign tourthe course of an entire year, foreign tourists outnumber local residents by more than 10.5 times. ists on Phuket as permanent residents, and ove 
in one way or another, benefited from tourism development, the benefits have proven greater for some than for others. Local landowners, and the urban Sino-Thai elite of the island in particular, have gained the most from tourism's meteoric expansion and have dominated the industry since the early 1970s by providing the majority of incipient capital for accommodation facilities and tourist services (Cohen, 1982). Conversely, residents with little capital or land holdings soon found themselves increasingly marginalized as the tourism industry quickly upgraded and expanded (Ing \& Jay, 1991; Rattachumpoth, 1992). The proliferation of brothels, massage parlors, and "girlie bars" in the popular beaches of Phuket has also exacerbated a range of social problems ranging from crime and prostitution to AIDS and child pornography (Morel \& Fein, 2008; Morison, 2008a).

The most obvious sign that Phuket as a destination is seemingly following the transition from CAT to UMT is the environmental damage caused by unregulated growth in both tourist numbers and accommodation facilities. Aside from the sheer aesthetic impact of altered visual landscapes, tourism in Phuket has placed enormous stress on a number of specific resources, including fresh water, coral, and land. As a small island, Phuket lacks abundant sources of fresh water. This remains manageable with a small local population but becomes a severe problem when the total population, including tourists, more than doubles within the span of a few years as it did during the 1980s. As tourism has expanded, already-denuded forest and mangrove resources have endured encroachment (Gray, 2008), and hillsides have been depleted of their top soil as large amounts of land fill are transferred to tourist projects along the coast (Lertkittisuk, 1992b). The expansion of the island's population over the past two decades has also led to problems with waste disposal (Wipatayotin, 2007). Phuket's one garbage incinerator can handle only 225 tons per day, far short of the 500 tons produced every day (Yuttaworawit, 2008). Further, untreated sewerage continues to taint the clean, translucent sea water that once served as Phuket's fundamental touristic resource (Chia, 2000; Eamwiwatkit, 1997; Kaosa-ard, 1994; Traisawasdichai, 1991)

With such social and environmental problems, it is perhaps no surprise that Phuket has earned an international reputation as a prime example of tourism gone wrong. For example, in a $2004 \mathrm{Na}$ tional Geographic Traveler survey of 200 specialists in sustainable tourism, 115 of the world's most famous destinations were ranked according to criteria related to "cultural, environmental, and aesthetic integrity," and the Phuket area comes in almost dead last at 113th place, just behind Key West, Florida, and just ahead of the North Coas of Jamaica and Costa del Sol, Spain (Tourtellot, 2004). In this survey, Phuket and other low-scoring destinations are placed in the "Getting Ugly" category, which groups together "victims of crowding, poor planning, and greed" (Tourtellot, 2004 p. 66). Similarly, in a 2007 National Geographer Traveler survey, this time of 522 experts, 111 island destinations were ranked according to their "integrity of place," or the qualities that make them unique (Tourtellot, 2007, p. 120). Once again Phuket falls near the bottom of the rankings, with only 5 out of the 111 island destinations scoring lower.

Despite drawing decades of criticism, and experiencing several crises ranging from national political instability to natural disasters, Phuket has continued to bounce back from setbacks and appears to be entering its second decade of the development phase. This stage was briefly but abruptly interrupted by the tsunami of December 24, 2004 The tsunami killed 279 people in Phuket, of whom at least 111 were foreigners, and there are still 620 people (364 foreigners) missing and presumed dead (RICB, 2006, p. 5). The tsunami caused a $63 \%$ drop in international tourist arrivals in 2005, and it would have been perfectly reasonable to expect that the tsunami-coming on the heels of over 20 years of unmanaged tourism development-would signal the end of Phuket's development stage and quickly usher in a period of consolidation and then stagnation. Several observers (Ashayagachat, 2005; Huthasingh, 2005; Mowat, 2005; Raksakul, 2005; Tangwisutijit, 2005) held out hope that the rebuilding required after the tsunami would offer local and national tourism planners a chance to avoid the mistakes of the past that had turned Phuket into a renowned example of unsustainable mass tourism. Nevertheless, the quick return of international visitors in 2006 and 2007 (see Fig. 4), not to mention the many reports of "more of the same" kind of tourism development in Phuket (Chant, 2005; Morison, 2008b; Warunpitikul \& Tangwisdutijit, 2005), would indicate that neither stagnation nor careful reconstruction has occurred It therefore appears that Phuket has skipped its consolidation and stagnation stages and has instead continued its development, despite a devastating crisis that could have easily set the tourism industry back permanently.

Sea Kayaking and Phuket's

Ongoing Development Stage

An important reason for tourism's continued growth, which has allowed Phuket to remain in the development stage of the TALC model, is product diversification. With the ongoing proliferation of products and services, Phuket is able to attract not only a greater number of tourists but also differen segments of the international tourist market. Product diversification takes several forms, including entertainment-oriented activities such as cabare performances and Muay Thai boxing matches, personal services such as massage and spa treatments, and nature-oriented day trips. The various nature-oriented day trips available to tourists in Phuket fall into the category of soft ecotourism Unlike hard (Laarman \& Durst, 1993; Palacio \& McCool, 1997) or hard-core (Lindberg, 1991) forms of ecotourism, soft ecotourism according to Weaver (2005) is "associated with large number of participants who seek short-term, convenien ecotourism experiences as part of a multi-dimensional tourism trip mediated extensively by the tourism industry" (p. 23).

In the Phuket vicinity, aside from elephant trek king in small tracts of jungle or rubber plantations, the principal soft ecotourism activity is sea kayaking in Ao Phang Nga Marine National Park. Ao Phang Nga, a shallow bay that abuts Phuket's east coast, covers an area of 400 square kilometers and contains 161 islands, 40 of which rise to over 300 meters above sea level. The porous limestone islands found in Ao Phang Nga possess many dramatic topographical features, including caves and enclosed lagoons, known as hong, the Thai word for "room." The topographic features of Ao Phang Nga provide a stunning backdrop for day cruises and also make it possible for tourists to escape the chaotic, built-up environments of Phuket's popular beaches. This has been true since tourists firs came to Phuket in the 1970s, but what changed in the late 1980s with the formation of SeaCanoeand has continued with the emergence of the othe sea kayaking companies - is that tourists are now being brought into the caves and lagoons, areas that had previously remained isolated or even unknown.

Although much of the criticism of certain smaller, more recently founded sea kayaking companies in Phuket stems partly from business rivalry, coming in many cases either from John Gray (2006), founder of SeaCanoe, or former managers of SeaCanoe (Shepherd, 2003), it is nevertheless true that a number of the approximately 20 sea kayaking companies engage in unsafe (Mecir, 2000) or environmentally irresponsible practices, including bringing too many people into the caves and lagoons at once and allowing customers to collect plant souvenirs, feed macaque monkeys, and engage in loud behavior while in the lagoons. On the whole, however, regardless of the problems linked to some sea kayaking operators, soft ecotourism in Phuket is indeed ecotourism and, in the case of the industry leaders especially, conforms to the majority of components of even the most comprehensive definitions of ecotourism (see Kontogeorgopoulos, 2004b).

The actions and policies of many of Phuket's sea kayaking companies, most notably the five that have operated since the early 1990s, measure favorably against The International Ecotourism Society's (TIES) Ecotourism Guidelines for $\mathrm{Na}$ ture Tour Operators (Wood, 2002). TIES guidelines encourage operators to educate travelers, minimize visitor and company impacts, provide staff training, contribute to conservation, and provide competitive local employment. As mentioned, some sea kayaking companies fail to abide by ecotourism principles, but many operators follow at least some of the TIES guidelines, principally because SeaCanoe has promoted ecotourism principles since its establishment. As descendents (and in some cases carbon copies) of SeaCanoe, Phuket's sea kayaking companies necessarily simulate many of those policies and especially practices that have made SeaCanoe and, more recently, 
JGSC internationally renowned ecotourism case studies.

Reflecting the inclusion of education in virtually all definitions of ecotourism (Diamantis, 1999; Fennell, 2003), TIES guidelines state the importance of preparing travelers with adequate cultural and environmental information. During the 90-minute trip aboard the escort boats to the islands of Ao Phang Nga, lead guides present information about the day's itinerary and, in most cases, information about the geological history of Ao Phang Nga. During the on-board presentation, the lead guide in six out of the eight companies surveyed holds in his hands a bound folder containing laminated information sheets. Even though tourists are kept busy for most of the day, $61 \%$ of sea kayaking passengers surveyed browse through the folder on their own at some point during the trip. The most important source of education comes from the kayaking guides, who are usually assigned two passengers each for the entire day. While kayaking in the lagoons with their customers, guides share information about what the tourists see, though their language skills vary greatly on an individual basis and across different companies. In any case, there is a high level of tourist satisfaction with the quality of kayaking guides (quality being defined as both service and knowledge). On the survey administered to sea kayaking customers, the ranking of the "quality of your guide today" was second highest out of 14 items (8.95 on a 10-point Likert scale). As soft ecotourists, sea kayaking customers are not necessarily motivated by a thirst for educational experiences, so the provision of information regarding the flora, fauna, and geology of Ao Phang Nga is especially important in promoting the educational goals of ecotourism. Most sea kayaking customers finish their trips with both an improved geographical knowledge of Ao Phang Nga and a heightened sense of environmental awareness and appreciation. In particular, $38 \%$ and $45 \%$ of customers answered "definitely" and "probably," respectively, when asked whether the sea kayaking day trip made them more aware about the natural environment.

TIES guidelines suggests that operators minimize visitor and nature tour company impacts through such actions as leading by example, taking corrective actions, and maintaining small group size. For many years, SeaCanoe and some of the older copycat companies carefully monitored their overall tourist numbers to limit the social and environmental impacts of their activities. Until the early 2000s, SeaCanoe rarely handled more than 64 passengers per day, even durin peak periods of the high tourist season. Unfortunately, the growth in competition among sea kay aking companies has meant that to remain economically viable, operators are now forced to bring more tourists into the lagoons than in the past. It is important to note that the limited carrying capacity, and to a lesser degree the national park status of Ao Phang Nga, greatly constrain the number of customers that these companies can bring into the area. Operating in a fixed number of caves, and in a fixed amount of space, sea kayaking companies compete fiercely with one another to bring tourists to the same caves and lagoons. Although this means that the caves and lagoons are more crowded than they once were, group size is necessarily limited due to natural geographical constraints. In the case of JGSC, which is the only operator to run trips in the late afternoon and early evening, the impact is limited and the number of customers on each escort boat remains on the low side $(16-20)$ due to the absence of other companies at this time of day. In any case, all eight companies profiled in the research for this article attempt to limit the impac of their customers through verbal and visual (in the informational folders) reminders about the need to refrain from littering, touching the cave walls, and shouting or smoking in the lagoons.

One way that TIES encourages operators to promote conservation is by supporting "parks and protected areas, paying entry fees at all times" (Wood, 2002, p. 34). Currently, park rangers approach every sea kayaking expedition to documen the number of passengers so that the rangers could each week collect 200 baht (\$6.14) per passenger at the offices of the kayaking operators. (It should be noted that owners, managers, and staff of sea kayaking companies widely acknowledge that park entry fees collected by the Ao Phang $\mathrm{Ng}$ National Park staff are pilfered and not sent to
Bangkok, where they are supposed to go toward conservation.)

The employment of locals in well-paid, rewarding jobs is the most significant way in which sea kayaking in Ao Phang Nga contributes to ecotourism. Unlike hotels, restaurants, and other more typical source of employment in the tourism industry, sea kayaking attracts only those Thais who are atypically unafraid of the ocean and willing to work outdoors for most of day. In other words, sea kayaking employment is automatically oriented toward locals due to the requirements of working in a marine environment. This is why just over half of all sea kayaking guides and close to $90 \%$ of on-board cooks, deckhands, and boat captains are native residents of Ko Yao Yai, an island off the east coast of Phuket that is home to several fishing villages (see Fig. 1)

What is noteworthy about the employment provided by sea kayaking companies is not just that it draws largely from local communities but also that it is regarded as good work by locals. SeaCanoe guides earn about eight times the nationa per capita average wage, and even the wages of cooks, the lowest paid of Sea Canoe's full-time employees, are almost five times greater than the average wage for clerical, sales, and services workers in southern Thailand (Kontogeorgopoulos, 2005). Formal and informal interviews with guides and other staff members of sea kayaking firms affirmed repeatedly that working in this soft ecotourism sector of Phuket's tourism industry featured much more itsara (freedom) and remained more lucrative, sanuk (fun), and interesting than previous sources of employment, be they fishing, farming, rubber tapping, or other tourismrelated jobs. Most important, considering that on one hand, only $15 \%$ of all sea kayaking employees surveyed had attained more than the grade 9 education required by Thai law, and on the other, at least one-third of the guides working for sea kayaking companies belong to the ethnic-Malay Muslim minority of Thailand, a traditionally marginalized group that features high rates of illiteracy and poverty (Che Man, 1990; McCargo, 2007), clearly soft ecotourism in Phuket offers revenue opportunities otherwise unavailable to poorly educated or marginalized members of Thai society.
Soft Ecotourism and the Reemergence of Alternative Tourism

To most scholars and practitioners, it would normally go without saying that ecotourism is a example of alternative tourism (Boyd, 2000; Fennell, 2003; Fennell \& Dowling, 2003; Page \& Dowling, 2002). However, some would likely view soft ecotourism in Phuket as either a watered-down, bastardized form of ecotourism or as mass ecotourism (Kontogeorgopoulos, 2003; Mastny, 2001; Pleumarom, 1993; Weaver, 2005; Weaver \& Lawton, 2007). Due to the "soft," passive nature of ecotourism in Phuket and the structural intersections between sea kayaking and the conventional, mass tourism industry, it would be reasonable to judge sea kayaking and soft ecotourism generally as part of either SMT or UMT, depending on the level of regulation (Weaver, 2000). Technically, though, despite exhibiting many of the hallmarks of UMT destinations, the Phuket vicinity also simultaneously features subsectors of the overall industry, such as sea kayaking, that display many characteristics associated with alternaive tourism. In other words, the Phuket "destination," which includes the island itself as well as adjacent Ao Phang Nga, is an example of the coexistence of mass and alternative tourism in the same location at the same time.

Alternative tourism is a vague catch-all term, and in general connotes a form of tourism that stands in contrast to mass tourism, defined by most authors as standardized, rigidly packaged, inflexible, and undifferentiated travel that is consumed en masse (Poon, 1993; Wearing \& Neil, 1999). Aside from the various ways noted earlier in which companies provide locals with training and employment benefits, sea kayaking is attractive precisely because of its flexibility and individual attention. Daily sea kayaking itineraries differ according to varying tidal patterns, thereby fostering a sense of adventure and spontaneity among passengers, who enjoy knowing that each trip is different. Thus, even on fairly standardized day trips, tourists enjoy a sense of flexibility not typically found in most other packaged tour itineraries in southern Thailand. Personal customer attention is a key feature of sea kayaking trips. Passengers 
leave the trip with an impression of personal service; a high staff-to-tourist ratio also encourages extensive one-on-one interactions and conversations between individual passengers and guides. In interviews with and surveys of sea kayaking passengers, the individual service and attention of the kayaking guides is rated as the most impressive aspect of the trip. Largely as a result of the flexible itineraries and individual attention paid to customers, $97 \%$ of sea kayaking customers state that they would "definitely" (80\%) or "probably" (17\%) recommend the trip to others.

In an early attempt to define alternative tourism, Cohen (1989) argued that the movement toward more alternative forms of tourism would consist of two basic elements. First, a growing awareness about the damaging effects of tourism would foster a sense of concern among some tourists. Second, a countercultural reaction among (mostly) young North Americans and Europeans against consumerism would produce alienation, which in turn would engender a desire for authenticity, defined in this case as a search for nonmodern and non-Western people and places. Hence, alternative tourism can be seen as an ethical concern for tourism hosts, on one hand, and a search for authenticity, on the other. Sea kayaking companies and customers display both of these traits. Companies attempt to limit their impacts in ways outlined ealier in this section, and every c outlined earlier in this section, and every company emphasizes and even stages the natural authenticity of the sea kayaking experience (Kontogeorgopoulos, 2004a). Kayaking customers also care about the impact of their travel on host communities: $86 \%$ of those surveyed agree or strongly agree that international tourism should be more responsive to the needs of local communities. Additionally, $60 \%$ of customers choose to participate in sea kayaking to "experience authentic Thai natural settings": this was the third most commonly cited motivation, among nine items, chosen by surveyed customers.

Sea kayaking in Phuket not only features many elements of alternative tourism in general, but also fits many of the criteria of the more specific category of CAT proposed by Weaver $(2000$, p. 218) It should be stated that the example of sea kayaking in Phuket is certainly not the CAT of the "exploration" or "involvement" stages of the Butler
TALC sequence, but it does share several of its features. First the attractions of CAT are area specific and "authentic." The drowned karst land scape of Ao Phang Nga is found in only a few other places in the world, which makes it both area-specific and authentic. Further, because there are no built, human-made features in the caves or lagoons into which sea kayaking companies travel, Ao Phang Nga is perceived by $89 \%$ of sea kayaking customers as authentic. Second, the strong internal linkages and minimal leakages associated with CAT also characterize sea kayaking in Phuket. SeaCanoe and JGSC spend roughly $95 \%$ percent of their in Thailand, and the small size of the majority of sea kayaking companies means that their spending patterns are mostly local or regional. Other than the inflatable kayaks used by the companies, there are few items that require spending money outside the local economy.

Like CAT, the existence of soft ecotourism in Phuket is purely coincidental and unplanned. Phuket tourism officials have exhibited a laissez-faire approach to all tourism development there (Krutwaysho, 2003), and this has meant a complete lack of regulations or standards for the sea kayaking industry. Last, sea kayaking in Phuket and Ao Phang Nga features low total volume. The issue of scale and volume is tricky. The difference between low-volume and high-volume destinations, as ideal types, is obvious to most observers, but it is unclear where to draw the line between activities that are large scale and those that are not. Within the high-volume destination of the Phuket vicinitywhere tourists greatly outnumber locals over the course of a year-Ao Phang Nga itself hosts a very small percentage of all tourists in Phuket and Phang Nga provinces. The owners and managers of sea kayaking companies interviewed for this research estimate that there are, on an average day, between 200 and 400 sea kayaking customers per day in Ao Phang Nga. On an annual basis, this translates to between 73,000 and 146,000 sea kayaking customers per year. If one were to take the average of these figures $(109,500)$, this means that sea kayaking customers represent only $3.5 \%$ of all international tourists in Phuket in 2007. Even if one includes the other 2,000 or so tourists, according to the owners and managers, in Ao Phang Nga every day participating in activities other than sea kayaking, the total number of tourists in Ao Phang Nga still comes out to only $17 \%$ of all visitors to Phuket, including both domestic and international tourists and daily excursionists.

In his original TALC model, Butler pointed out that one of the characteristics of the development stage is the identification and marketing of natural and cultural attractions. Butler never explicitly states whether such attractions are supplied by operators in anticipation and hope of further tourism growth or demanded by greater numbers of tourists. In the case of Phuket, soft ecotourism is supplied by operators to attract more business, but more important, it is also an example of how mass tourism itself has created a demand for alternative tourism experiences. In particular, initial notions among entrepreneurs such as John Gray that there even existed a need for ecotourism in Phuket stemmed from what these entrepreneurs perceived as the harmful environmental and social consequences of rapid tourism development during the 1980 s. As survey data confirm, the steady transformation of Phuket into a congested mass tourism beach environment has directly stimulated heightened tourist demand for novel, adventurous, and nature-oriented experiences removed both spatially and psychologically from the shops, touts, and traffic congestion of main resort areas. Hence, the rising demand for and interest in soft ecotourism represent a collective market reaction and byproduct of the ecological damage, personal detachment, and social conflict associated with mass, packaged tourism development in Phuket (Cohen, 1996).

\section{Conclusion}

Contrary to predictions of a unilinear progression from alternative to mass tourism, evidence from the Phuket vicinity illustrates that certain localized forms of alternative tourism, such as sea kayaking, not only follow the establishment of conventional mass tourism but also come to depend structurally and spatially on the tourist markets, marketing channels, and business networks made possible by mass tourism. This does not necessarily deny the accuracy of predictions regarding the inclination of mass tourism to come along and replace its small-scale alternative predecessor;
Phuket's early evolution as a tourism destination certainly confirms this pattern. However, the assumption that only travel to remote areas by small groups of explorers qualifies as alternative tourism is contradicted by the emergence of soft ecotourism companies in Phuket that promote in their daily practices many of the principles associate with ecotourism. Compared to early manifestations of alternative tourism in Phuket, such as backpacking, soft ecotourism may indeed differ in scale, clientele, and intensity, but it nevertheles still signals the emergence of alternative tourism long after the exploration and involvement stages of tourism.

Aside from challenging the central assumption that alternative tourism can only precede (an never follow) mass tourism, the example of sea kayaking in Phuket and Ao Phang Nga contributes two insights to the temporal study of tourism. First, although Butler (1980) lists the developmen of natural and cultural attractions as merely one of many features associated with the developmen stage of a destination area's evolution, no mention is made of the possibility that, on one hand, such attractions may constitute alternative tourism, and that, on the other, these emergent forms of alternative tourism may, in concert with other examples of product diversification, act to delay the inevitable stagnation of a mass tourism destination. As illustrated in this article, Phuket has remained in the development stage of Butler's model, despite numerous crises and ample evidence of unsustainable growth. Soft ecotourism is therefore likely one of many activities, services, and attraction that have allowed Phuket to continue growing as a tourism destination. Though only $8 \%$ of sea kay aking customers surveyed or interviewed for this article came to Phuket specifically because of opportunities to participate in sea kayaking, $75 \%$ admitted that the excursions offered by Phuket's soft ecotourism companies have contributed to the likelihood that they might return to this area in the future. It would be highly inaccurate to claim that soft ecotourism is on its own delaying Phuket's stagnation, but sea kayaking in Ao Phang Nga is nevertheless one of several components of the product diversification that has contributed to Phuket's ongoing growth.

Second, this article presents empirical evidence 
that both confirms and extends the only known theoretical application of Butler's model to mass and alternative tourism specifically (Weaver, 2000). Phuket confirms the CAT to UMT scenario in that small-scale alternative tourism made way in the 1980s and 1990s to high-intensity and, according to some observers, unsustainable mass tourism. At the same time, soft ecotourism emerged during Phuket's development stage as a hybrid form of alternative tourism in the midst of a mass tourism setting. The inability of Weaver's broad context model of destination development scenarios to accommodate both mass and alternative forms of tourism simultaneously hints at what Haywood $(1986,2006)$ and others point out as a limitation of the original Butler model: what exactly is a destination? If one were to examine just Patong Beach, Phuket's most developed resort area, then it would be hard to argue that it represents anything other than UMT. However, if the entire Phuket vicinity, including Ao Phang Nga, were treated as a destination, one would find mostly UMT but also pockets of alternative tourism, such as sea kayaking and other forms of soft ecotourism. Moreover, on a national scale, multiple forms of tourism, at various stages, coexist simultaneously, demonstrating once again that defining the destination in question is crucial in any life-cycle analysis.

The scale and timing of soft ecotourism in Phuket illustrate that alternative tourism comes in a variety of forms and in practice can involve more than just the activities of hard-core ecotourists in remote locations (Lindberg, 1991). Although it remains to be seen how long Phuket can avoid stagnation and decline, it is clear that soft ecotourism has contributed to the region's attractiveness while also developing as a result of mass tourism growth, thereby necessitating a reexamination of conventional approaches that posit a temporal shift from alternative tourism to mass tourism, but not the other way around.

\section{References}

Agarwal, S. (2002). Restructuring seaside tourism: The resort life-cycle. Annals of Tourism Research, 29(1), $25-55$

Ashayagachat, A. (2005, January 19). Disaster "a blessing in disguise." Bangkok Post, p. A3.
Baum, T. (1998). 'Taking the exit route: Extending the tourism area life cycle model. Current Issues in Touris I(2), 167-175.

Boyd, S. (2000). Tourism, national parks and sustainability. In R. Butler \& S. Boyd (Eds.), Tourism and national parks: Issues and implications (pp. 161-186). Chichester, UK: Wiley.

Buckley, R. (2003). Case studies in ecotourism. Wallingford, UK: $\mathrm{CAB}$

Butcher, J. (2003). The moralization of tourism: Sun, sand and saving the world? London: Routledge.

Butler, R. (1980). The concept of a tourist area cycle of evolution: Implications for management of resources. Canadian Geographer, 24(1), 5-12

Butler, R. (1992). Alternative tourism: The thin end of the wedge. In V. Smith \& W. Eadington (Eds.), Tourism alternatives: Potentials and problems in the develop ment of tourism (pp. 31-46). Philadelphia: University of Pennsylvania Press.

Butler, R. (Ed.). (2006a). The tourism area life cycle, vol. 1: Applications and modifications. Clevedon, UK: Channel View.

Butler, R. (Ed.). (2006b). The tourism area life cycle, vol. 2: Conceptual and theoretical issues. Clevedon, UK: Channel View.

Butler, R. (2006c). Foundations of the TALC. In R. Butler (Ed.), The tourism area life cycle, vol. I: Application and modifications (pp. 1-2). Clevedon, UK: Channe View.

Cater, C., \& Cater, E. (2007). Marine ecotourism: Between the devil and the deep blue sea. Wallingford, UK: CABI.

Chant, A. (2005, December 27). Thailand accused of touting for tourists. Times [UK], p. 7. Retrieved from LexisNexis Academic database.

Che Man, W. K. (1990). Muslim separatism: The Moros of southern Philippines and the Malays of southern That land. Singapore: Oxford University Press.

Chia, L. S. (2000). Overview of impact of sewage on the marine environment of East Asia: Social and economic opportunities. EAS/RCU Technical Report Series, no. 15. Bangkok: United Nations Environment Program. Retrieved from http://www.cobsea.org/documents/report landbased/Overview_Impact_Sewage_on_the_Marine Environment.pdf.

Cohen, E. (1973). Nomads from affluence: Notes on the phenomenon of drifter tourism. International Journal of Comparative Sociology, 14(1\&2), 89-103.

Cohen, E. (1982). Marginal paradises: Bungalow tourism on the islands of southern Thailand. Annals of Tourism Research, 9(2), 189-228.

Cohen, E. (1989). "Alternative tourism": A critique. In T V. Singh, H. L. Theuns, \& F. M. Go (Eds.), Towards appropriate tourism: The case of developing countries (pp. 127-142). Frankfurt: Peter Lang.

tribes, islands, and kok: White Lotus.

Diamantis, D. (1999). The concept of ecotourism: Evolu-
Eamwiwatkit, W. (1997, May 17). Soil erosion sullies Phuket sea water. The Nation [Bangkok], p. A12.

Fennell, D. (2003). Ecotourism: An introduction (2nd ed.) London and New York: Routledge.

Fennell, D., \& Dowling, R. (Eds.). (2003). Ecotourism policy and planning. Wallingford, UK: $\mathrm{CABI}$

Graber, K. (1997). Cities and the destination life cycle. In J. A. Mazanec (Ed.), International city tourism: Analysis and strategy (pp. 39-53). London: Pinter.

Gray, J. (2006, March). Guide for dangerous sports. Phuke Gazette. Retrieved from http://www.johngray-seacanoe. com/documents/grayarea/guide_sports.htm.

Gray, J. (2008, April 12-18). Boomtown business leaves scenery scarred. Phuket Gazette, p. 26

Haywood, K. M. (1986). Can the tourist area life-cycle be made operational? Tourism Management, 7(3), 154167.

Haywood, K. M. (2006) Legitimizing the TALC as a theory of development and change. In R. Butler (Ed.), The tourism area life cycle, vol. 2: Conceptual and theoreti cal issues (pp. 29-44). Clevedon, UK: Channel View.

Huntington Technical Services. (1974). South Thailand regional planning study. London: Huntington Technical Services.

Huthasingh, O. (2005, December 31). Wave a blessing for island wildlife. Bangkok Post, p. A2

Ing, K. (1988a, May 16). Paradise lost. The Nation [Bangkok], p. 31.

Ing, K. (1988b, May 17). One person's paradise is another's hell. The Nation [Bangkok], p. 31.

Ing, K. (Writer), \& Jay, D. (Producer and Director). (1991) Thailand for sale [Motion picture]. Bendigo, Australia: Video Education Australasia.

Janviroj, P. (1988, May 10). Tourism overkill in Phuket: It's time to pay more attention to conservation. The $\mathrm{Na}$ tion [Bangkok], p. 8.

Johnston, C. S. (2001). Shoring the foundations of the destination life cycle model. Part I: Ontological and epistemological considerations, Tourism Geographies 3(1), 2-28.

Kaosa-ard, M. S. (1994). Thailand's tourism industry: What do we gain and lose? TDRI Quarterly Review, 9(3), 23-26.

Kontogeorgopoulos, N. (1998). Accommodation employment patterns and (19portunities. Annals of Tourism Research, 25(2), 314-339.

Kontogeorgopoulos, N. (2003). Towards a Southeast Asian model of resort-based "mass ecotourism": Evidence from Phuket, Thailand and Bali, Indonesia. ASEAN Joumal on Hospitality and Tourism, 2(1), 1-16.

Kontogeorgopoulos, N. (2004a). Ecotourism and mass tourism in southern Thailand: Spatial interdependence, structural connections, and staged authenticity. GeoJournal, 61, 1-11.

Kontogeorgopoulos, N. (2004b). Conventional tourism and ecotourism in Phuket, Thailand: Conflicting paradigms ontogeorgopoulos, N. (2005). Community-based ecotourism in Phuket and Ao Phangnga, Thailand: Partial victories and bittersweet remedies. Journal of Sustainable Tourism, 13(1), 4-23.

Krutwaysho, O. (2003, April). Obstacles to the implementation of tourism policies and regulations in Phuket. Thailand. Paper presented at the 12th International Tourism and Leisure Symposium, Barcelona, Spain. Retrieved from http://www.esade.es/cedit2003/pdfs/krut wayshooratai.pdf.

Laarman, J., \& Durst, P. (1993). Nature tourism as a tool for economic development and conservation of natural resources. In J. Nenon \& P. Durst (Eds.), Nature tourism in Asia: Opportunities and constraints for conservation and economic development (pp. 1-19). Washin ton, DC: U.S. Forest Service.

A lite R. (2006). The application of the TALC model: A literature survey. In R. Butler (Ed.), The tourism area life cycle, vol. I: Applications and modifications (pp. 27-50). Clevedon, UK: Channel View.

Lertkittisuk, P. (1992a, January 26). Phuket: Victim of greed. Bangkok Post, pp. A8-A9.

Lertkittisuk, P. (1992b, January 26). A tourism disaster in the making. Bangkok Post, p. A8.

indberg, K. (1991). Policies for maximizing nature tourism's ecological and economic benefits. Washington, DC: World Resource Institute.

Lück, M. (2002). Large-scale ecotourism: A contradictio in itself? Current Issues in Tourism 5(3\&4), 361-370.

Ludwig, H. (1976, May/June). Environmentalism and Phuket: A case study. Sawaddi Magazine, pp. 14-17, $22-25$

Mann, M. (2002). The good alternative travel guide (2nd ed.). London: Earthscan and Tourism Concern.

Mastny, L. (2001). Traveling light: New paths for international tourism. Washington, DC: Worldwatch.

McCargo, D. (Ed.). (2007). Rethinking Thailand's souther violence. Singapore: NUS Press.

Wildlife, 30(6), 28-36.

adise-or province of peril. $P h$ 12-18). Our tropical parMorison, A. (2007, November 25). Phuket's , pp. 4-5. drome. Phuket Wan. Retrieved from http://phuketwan. com/article/tourism/phukets-self-harm-syndrome.

Morison, A. (2008a, April 2). Nightmare exposed: Childre for sale on Phuket. Phuket Wan. Retrieved from http./ phuketwan.com/article/tourism/children-for-sale-in-phuke -exploitation-nightmare-exposed.

Morison, A. (2008b, May 4). Answer needed to Phuket'

biggest question. Phuket Wan. Retrieved from http: phuketwan.com/article/tourism/trends-answer-needed-to -phukets-biggest-question.

Moss, S. E., Ryan, C., \& Wagoner, C. B. (2003). An empirical test of Butler's resort product life cycle: Forecasting 
casino winning. Journal of Travel Research, 41(4), 393-399.

Motavalli, J., \& Honey, M. (2002, July/August). Taking the natural path. E: The Environmental Magazine, 13, 26-37.

Mowat, G. (2005, April 7). Paradise lost and found. Bangkok Post, p. H4.

Neale, G. (1999). The Green Travel Guide. London: Earthscan.

O'Hare, G., \& Barrett, H. (1997). The destination life cycle: International tourism in Peru. Scottish Geographical Magazine, 113(2), 66-73.

Page, S., \& Dowling, R. (2002). Ecotourism. Harlow, UK: Prentice Hall.

Palacio, V., \& McCool, S. (1997). Identifying ecotourists in Belize through benefit segmentation: A preliminary analysis. Journal of Sustainable Tourism, 5(3), 234243.

Pleumarom, A. (1993). What's wrong with mass ecotourism? Contours 6(3/4), 15-21.

Pleumarom, A. (1994). Sport and environment: Thailand's golf boom reviewed. Thailand Environment Institute (TEI) Quarterly Environment Journal, 2(4), 47-61.

Pleumarom, A. (2001). Mekong tourism: Model or mockery? Penang, Malaysia: Third World Network.

Poon, A. (1993). Tourism, technology, and competitive strategies. Wallingford, UK: CABI.

Priestley, G., \& Mundet, L. (1998). The post-stagnation phase of the resort life-cycle. Annals of Tourism Research, 25(1), 85-111.

Raksakul, S. (2005, November 13). Nature gets a second chance. Bangkok Post, p. A5.

Rattachumpoth, R. (1992). Phuket: Holiday paradise where locals are banned. Contours, 5(8), 13-15.

Research and International Cooperation Bureau (RICB). (2006). Thailand: Country report. Bangkok: Department of Disaster Prevention and Mitigation, Ministry of Interior. Retrieved from http://www.disaster.go.th/html/ english/info_center/country_reports/01_Thailand_Coun try_report_2006b.pdf.

Ross, D. (2002, July 6). Squalor on Patong. Bangkok Post, Horizons section, p. 9.

Russell, R. (2006). Chaos theory and its application to the TALC model. In R. Butler (Ed.), The tourism area life cycle, vol. 2: Conceptual and theoretical issues (pp. 164-180). Clevedon, UK: Channel View.

Shepherd, N. (2003). How ecotourism can go wrong: The cases of SeaCanoe and Siam Safari, Thailand. In M. Luck \& T. Kirstges (Eds.), Global ecotourism policies and case studies (pp. 137-146). Clevedon, UK: Channel View.

Tangwisutijit, N. (2005, March 2). Environment shining in wake of disaster. The Nation [Bangkok], p. A3.

Thaitakoo, D. (1994). Phuket: Urban conservation versus tourism. In M. Askew \& W. Logan (Eds.), Cultural identity and urban change in Southeast Asia (pp. 135147). Geelong, Australia: Deakin University Press.

Tourism Authority of Thailand (TAT). (1979). Masterplan and feasibility study: Tourism development of Phuket. Bangkok: TAT.

Tourism Authority of Thailand (TAT). (2008). Domestic tourism statistics. Retrieved from http://www2.tat.or.th/ stat/web/static_tst.php.

Tourtellot, J. (2004, March). Destination scorecard: 115 places rated. National Geographic Traveler, 21, 60-67.

Tourtellot, J. (2007, November/December). 111 islands. National Geographic Traveler, 24, 108-121.

Traisawasdichai, M. (1991, March 21). The rape of a southern belle. The Nation [Bangkok], pp. C1-C2.

Viviano, L. (2002). Escaping from reality. Ecologist, 32(2), 26-31.

Warunpitikul, Y., \& Tangwisutijit, N. (2005, March 7). The lesson not learned. The Nation [Bangkok], p. A3.

Wearing, S., \& Neil, J. (1999). Ecotourism impacts, potentials and possibilities. Melbourne: Butterworth-Heinemann.

Weaver, D. B. (2000). A broad context model of destination development scenarios. Tourism Management, 21(3), 217-224.

Weaver, D. B. (2001). Ecotourism as mass tourism: Contradiction or reality? Cornell Hotel and Restaurant Administration Quarterly, 42(2), 104-112.

Weaver, D. B. (2002). The evolving concept of ecotourism and its potential impacts. International Journal of Sustainable Development, 5(3), 251-264.

Weaver, D. B. (2005). Mass and urban ecotourism: New manifestations of an old concept. Tourism Recreation Research, 30(1), 19-26.

Weaver, D. B. (2006). Sustainable tourism: Theory and practice. London: Elsevier Butterworth-Heinemann.

Weaver, D. B., \& Lawton, L. (2002). Tourism management (2nd ed.). Milton, Australia: John Wiley.

Weaver, D. B., \& Lawton, L. (2007). Twenty years on: The state of contemporary ecotourism research. Tourism Management, 28, 1168-1179.

Wipatayotin, A. (2007, July 23). Island's waste problem mounting. Bangkok Post. Retrieved from http://www. bangkokpost.com/News/ 23Jul2007_news06.php.

Wong, P. P. (1995). Tourism environment interaction in the western bays of Phuket island. Malaysian Journal of Tropical Geography, 26(1), 67-75.

Wood, M. E. (2002). Ecotourism: Principles, practices and policies for sustainability. Paris: UNEP Division of Technology, Industry and Economics; and Burlington, VT: International Ecotourism Society.

Yuttaworawit, N. (2008, April 19-25). Saphan Hin incinerator given top-level support. Phuket Gazette, p. 3. 